\title{
Caracterización de materiales antiguos de construcción (tapial y adobe) en las iglesias de Cisneros, Villada y Boada de Campos (Palencia)
}

\section{Characterization of ancient construction materials (mud walls and adobe) in the churches at Cisneros, Villada and Boada de Campos (Palencia)}

R.SÁNCHEZHERNÁNDEZ, M.SÚAREZ BARRIOS,y J.M.MARTÍN POZAS

Dpto. de Geología. Universidad de Salamanca

Fecha de recepción: 18-XI-98

Fecha de aceptación: 22-II-99

ESPAÑA

\section{RESUMEN}

El objetivo de este trabajo es caracterizar los materiales antiguos de construcción (tapial y adobe) de tres iglesias en la propincia de Palencia. El trabajo es la primera parte de un estudio en el que se pretende evaluar el comportamiento de los tapiales de la torre de la iglesia de Cisneros frente al tratamiento de restauración, consistente en un cosido estructural mediante la realización de perforaciones en las que se introduce una barra de acero y donde, posteriormente, se inyecta una lechada muy fluidificada de mortero de cemento/cal/arena. Este tratamiento implica la introducción en las fábricas de grandes cantidades de agua.

Los tapiales de la torre de Cisneros son, composicional y texturalmente, muy similares entre sí, lo que indica que, a pesar de sus grandes dimensiones, se cuidó la homogeneidad de los materiales. Estos tapiales guardan una notable similitud con los de la iglesia de Villada. La materia prima original es barro con algunos aditivos (escombro, cenizas, huesos, etc.) y algunos restos de cal empleada como estabilizante. Aunque la proporción de arcilla es muy elevada no se han detectado arcillas hinchables, de lo que se deduce que una vez construido el tapial no se habrian producido importantes cambios de volumen por variaciones de humedad de las fábricas.

Las caracteristicas del adobe de la torre de Boada son lógicamente diferentes de las de los tapiales estando constituido por un barro menos arenoso, más arcilloso, con una elevada proporción de paja que no tienen los tapiales y sin adiciones de ladrillos, huesos, etc.

\section{SUMMARY}

The aim of this work is to characterize the ancient building materials (mud wall and adobe) of three churches in the province of Palencia. This is the first part of a study which seeks to evaluate how the mud walls of the tower of the church of Cisneros reacted to restoration treatment which consisted of a structural reinforcement made by injecting a highly fluid grout of cement/lime/sand mortar. This treatment implies the introduction of large quantities of water into the fabric.

The mud walls of the tower of Cisneros are compositionally and texturally very similar to each other, which indicates that despite their large dimensions, care was taken in the homogeneity of the materials. These mud walls are also very similar to those of the church of Villada. The original raw material is mud with some additives (rubble, ashes, bones, etc.) and some remains of lime used as a stabiliser. Although there is a very high proportion of clay, no effervescing clay has been detected. Hence it is deduced that once the mud wall was built, there were no important changes in volume due to variation in the humidity of the fabric.

The characteristics of the adobe of the tower of Boada are logically different form those of the mud walls, being made of less sandy, more clayey mud with a high proportion of straw that the mud walls do not have, and without the addition of bricks, bones, etc. 


\section{INTRODUCCIÓN}

La tierra se ha utilizado a lo largo de la Historia como uno de los principales materiales de construcción, no sólo para viviendas sencillas, sino también para la realización de grandes obras monumentales. En nuestro país es importante el patrimonio construido con tierra siendo quizás su principal exponente la Alhambra de Granada en la que una parte importante está edificada con este material. En Castilla y León pueden encontrarse desde grandes iglesias y murallas hasta palomares construidos con tapial o adobe.

Existen dos tipos fundamentales de construcciones en tierra, el tapial o muro de tapia, que es un muro o pared realizada con tierra prensada en el interior de un molde o encofrado constituido por dos tableros verticales y paralelos, y el adobe que es una masa de barro moldeada en forma de ladrillo y secado al sol.

Frente a las ventajas de la tierra como material de construcción, derivadas de su bajo coste y facilidad de manipulación, aparecen los inconvenientes que tienen que ver con la facilidad que ofrece para ser erosionada por el viento y el agua, siendo los daños más frecuentes los relacionados con fisuraciones, disgregaciones y pérdidas de materia. La resistencia de los tapiales ante los factores erosionantes viene dada, fundamentalmente, por características tales como compacidad o la propia composición del mismo (1) y por la cantidad de agua que retiene en su interior (2). Para evitar la aparición de las mencionadas "patologías", suelen emplearse revestimientos o paredes externas de ladrillo, revocos u otros tratamientos que protegen los muros de la erosión y proporcionan estanquidad (3).

No es abundante la bibliografía existente relativa a estos materiales, pero se pueden encontrar algunos trabajos en los que se describen restauraciones de construcciones a base de tapial. Estas restauraciones suelen consistir en la reconstrucción, mediante técnicas tradicionales y materiales similares a los originales, de los paramentos perdidos total o parcialmente. Tal es el caso de las murallas de Niebla (4), Cáceres (5) o la Torre de la Sultana de la Alhambra de Granada (6). En algunos casos, como en el castillo de Toral de los Guzmanes, se han realizado cosidos de las fábricas, cosidos que aportan estabilidad a la construcción (7). En la Casa-Castillo de Bétera en Valencia (8), además de la reconstrucción de los paramentos, se emplearon cosidos estáticos de los muros de tapial mediante perforaciones de $3,5 \mathrm{~cm}$ de diámetro donde se inyectó una lechada de cemento.

El objetivo del presente trabajo es caracterizar los materiales antiguos de construcción (tapial y adobe) de

\section{INTRODUCTION}

Along the history of humankind, earth (in the form of mud) has always been used as one of the main construction materials, not only for simple dwellings but also for larger monumental works. In Spain, the heritage of mud-built constructions is very important, the most spectacular example being the Alhambra in Granada (a large part of it is made of mud). In the Regional Community of Castilla y León one finds constructions made of mud or adobe ranging from large churches to dovecots.

There are two main types of earth-based constructions: walls, consisting of earth compacted inside a mold comprising two vertical and parallel planks, and adobe, which is a mixture of mud and straw sun-dried in the shape of a brick and used as such.

In contrast to the advantages of the use of mud as a construction material -its low cost and ease in handling-its drawbacks include its susceptibility to erosion by the rain and the wind, the most important damage appearing as fissures, cracks and loss of material. The resistance of mud walls to weathering mainly depends on parameters such as their degree of compactness or composition (1) and the amount of water retained inside them (2). To avoid such "pathologies", mud walls are usually covered with an external layer of brick, plaster or other materials designed to protect the walls from erosion and preserve a "hermetic" environment (3).

There are few references to these materials in the literature, although some works have addressed the restoration of mud-built constructions. Such restoration work usually consists in reconstructing the partially or wholly lost elements using traditional techniques and materials similar to the original ones. Such is the case of the walls of Niebla (4), Cáceres (5) or the Torre de la Sultana of the Alhambra in Granada (6). In some cases, such as the castle at Toral de los Guzmanes, the fabric has been stapled to stabilize the construction (7). As well as surface restoration, at the Casa-Castillo de Bétera in Valencia (8) multipple fixed staples were used in the mud walls, In this case, cement was injected through $3.5 \mathrm{~cm}$ diameter orifices in the wall.

The aim of the present study was to characterize the original construction materials (mud and adobe) of the 
la iglesia de San Facundo y San Primitivo en Cisneros, San Fructuoso en Villada y San Pedro en Boada de Campos, todas ellas localizadas en la provincia de Palencia. En Cisneros el estudio se realizó con anterioridad a su intervención mientras que en Villada y Boada las torres habían sido restauradas con un año de antelación a base de inyección de una lechada muy fluida de este tipo.

Las iglesias de Cisneros y Villada (Figuras 1 y 2) poseen torres de gran esbeltez que se encuentran edificadas con tapial y refuerzo exterior de ladrillo. La torre de la iglesia de Boada (Figura 3) está construida churches of San Facundo and San Primitivo in Cisneros, San Fructuoso in Villada and San Pedro at Boada de Campos, all in the province of Palencia. At Cisneros, the study was carried out prior to the restoration work while at Villada and Boada de Campos the towers had been restored on the basis of the technique one year prior to the study.

The churches in Cisneros and Villada (Figures 1 and 2) have very slender towers whose walls are made of a mud core lined externally with brick. The base of the tower of the church in Boada de Campos (Figure 3) is made of mud while the rest is made of adobe.



Figura 1.- Torre de la iglesia de San Primitivo y San Facundo de Cisneros.

Figure 1.- Tower of the church of San Primitivo and San Facundo of Cisneros.

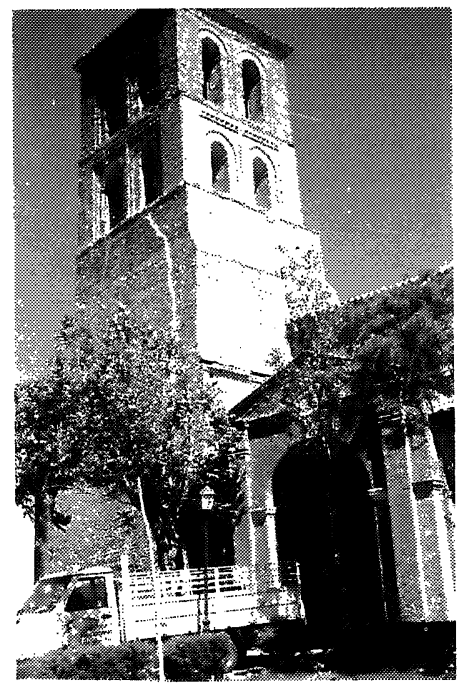

Figura 2.- Torre de la iglesia de San Fructuoso en Villada.

Figure 2.- Tower of the church of San Fructuoso in Villada.

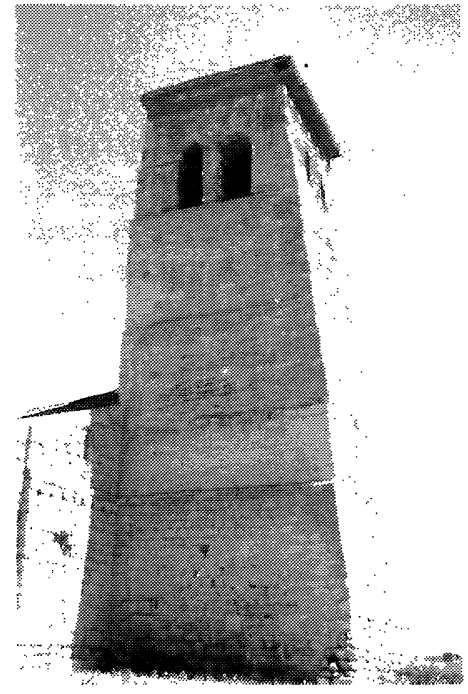

Figura 3.- Torre de la iglesia de San Pedro en Boada.

Figure 3.- Tower of the church of San Pedro in Boada. 
con tapial en la base y adobe en el resto de la torre, con refuerzo de piedra y ladrillo en el exterior.

\section{MATERIALES Y MÉTODOS}

En primer lugar se efectuó una inspección general de los materiales en cada una de las torres, procediendo a la extracción de muestras teniendo en cuenta dos criterios: representatividad y extracción del menor volumen de muestra posible. Así, para el estudio de los tapiales se tomaron tres muestras de tapial en la iglesia de Cisneros a diferentes alturas y orientaciones y una en la iglesia de Villada mientras que para el estudio del adobe se recogió una única muestra en la iglesia de Boada. Todas las muestras fueron extraídas en el interior de las torres y herméticamente cerradas para impedir la pérdida de humedad durante el transporte al laboratorio. La denominación de las muestras y su localización es la que se detalla a continuación.

En la iglesia de San Facundo y San Primitivo en Cisneros se recogieron tres muestras de tapial de un tamaño aproximado de $25 \times 25 \times 25 \mathrm{~cm}$. La muestra CIS1 está tomada en la cara Sur de la torre a una cota de $6 \mathrm{~m}$, mientras que CIS2 y CIS3 se localizan a una cota de 11,85 m en las caras Sur y Oeste respectivamente.

En la iglesia de Villada se ha recogido una muestra con el empleo de broca diamantada de gran diámetro para la extracción de testigos. Debido a las características de los tapiales, no fue posible la extracción completa de los testigos, sino de numerosos fragmentos de pequeño tamaño. La muestra denominada VI2, fue tomada en la cara Oeste de la torre a 1,65 $\mathrm{m}$ debajo del vano del campanario. Dicha muestra fue tomada en una zona muy próxima a uno de los puntos de inyección de mortero efectuada con un año de antelación.

En la iglesia de Boada tampoco fue posible la extracción completa de los testigos sino de fragmentos de adobe. La muestra BO1 fue extraída en la cara Este a $0,85 \mathrm{~m}$ sobre el forjado y $0,40 \mathrm{~m}$ de la pared Norte de la torre. Al igual que en Villada la muestra fue recogida en las proximidades de una de las inyecciones de mortero.

La descripción de las características macroscópicas de los tapiales y adobe se llevó a cabo mediante examen visual y con lupa binocular de 50 aumentos.

Se realizaron análisis mineralógicos por Difracción de Rayos-X para muestras de roca total (molidas con un molino THEMA hasta un tamaño inferior a $50 \mu \mathrm{m}$ ) en un equipo SIEMENS D-500 con anticátodo de $\mathrm{Cu}$,
Outside, the basement is reinforced with stone while the outside of the tower itself is reinforced with brick.

\section{MATERIALS AND METHODS}

We first made a general inspection of the material in each of the towers and then took samples taking into account two criteria: representativeness and the need to take the minimum amount of sample possible. Thus, in the case of mud samples we collected three samples of the mud wall of the church in Cisneros at different heights and orientations and one from the church in Villada while in the case of adobe we took a single sample from the church in Boada de. All samples were taken from the inside of the towers and were sealed in hermetic vessels to prevent loss of humidity during transport to the laboratory. Sample nomenclature and localisation are detailed below.

At the churches of San Facundo and San Primitivo, three samples of the mud wall were collected: sample volume was approximately $25 \times 25 \times 25 \mathrm{~cm}$. Sample CIS1 was taken from the south face of the tower at a height of $6 \mathrm{~m}$, while samples CIS2 and CIS3 were taken at a height of $11.85 \mathrm{~m}$ from the south and west faces, respectively.

At the church in Villada, we took a sample with the aid of a large-calibre diamond bit. Owing to the characteristics of the mud walls, it was not possible to extract intact cores; instead only small fragments could be collected. The sample designated V12 was taken from the West face of the tower at a height of $1.65 \mathrm{~m}$ below the belfry. This sample was taken from an area very close to one of the points of injection of mortar performed a year before.

At the church in Boada it was not possible to make a complete extraction of the samples either; again only fragments of adobe were obtained. The BOI sample was extracted from the East face of the tower at 0.85 $m$ above the belfry floor, at $0.40 \mathrm{~m}$ from the North wall of the tower. As in the case of the samples from Villada, the sample here was collected form an area close to the site of one of the earlier injections of mortar.

The gross characteristics of the mud wall and adobe samples were explored visually and using a binocular microscope at $x 50$ magnification.

Mineralogical analyses using X-Ray Diffraction (XRD) for total rock samples (ground in a THEMA mill to below $50 \mu \mathrm{m}$ ) were conducted on a SIEMENS $D$-500 apparatus with a $C u$ anticathode, $K \alpha$ 
radiación $\mathrm{K} \alpha$ y con monocromador de grafito. Las condiciones de trabajo han sido las siguientes: intensidad $30 \mathrm{~mA}$, potencial $40 \mathrm{Kv}$, velocidad de barrido $1^{\circ}$ de $2 \theta$ por minuto y la zona explorada de 3 a $65^{\circ}$ de $2 \theta$.

Para conocer la composición mineral de la fracción menor de $2 \mu \mathrm{m}$, separada por decantación, se realizaron análisis DRX en agregado orientado, solvatando las muestras con etilén-glicol y sometiendo las muestras a tratamiento térmico (calcinado a $550^{\circ} \mathrm{C}$ ) durante $2 \mathrm{~h}$.

Para la realización de las láminas delgadas las muestras fueron embutidas al vacío en resina de polimetacrilato para mantener la textura de los materiales a estudiar y evitar, en la medida de lo posible, la pérdida del material arcilloso en el proceso de pulido de las láminas. Estas láminas fueron observadas al microscopio óptico de polarización obteniéndose datos referentes a la composición del esqueleto y de la matriz, que actúan como el árido y el ligante del tapial respectivamente, y características de la porosidad.

Se realizó un análisis granulométrico por tamizado de una cantidad de entre 350 y $400 \mathrm{~g}$ de muestra previamente disgregada con un dispersante para separar las diferentes fracciones granulométricas. El dispersante empleado fue hexametafosfato sódico al $7 \%$. Posteriormente al tamizado, se pesan cada una de las fracciones que quedan retenidas en los diferentes tamices. Siguiendo la metodología de Diaz et al. (9) se eligieron los tamices de un análisis simplificado $(2,0,4$ y $0,08 \mathrm{~mm})$ y complementando con los tamices de 4, 1 y $0,177 \mathrm{~mm}$ intercalados entre los anteriores. Así la sucesión de tamices empleados fue $4,2,1,0,4,0,177$ y $0,08 \mathrm{~mm}$.

Por último, se completó el estudio del sistema poroso del tapial mediante la técnica de Porosimetría de Inyección de $\mathrm{Hg}$, realizado con un porosímetro marca Micromeritics, modelo 9320 , en un rango de presiones de 1 a 30.000 p.s.i. y habiendo desgasificando las muestras hasta una presión residual de $50 \mathrm{~mm}$ de $\mathrm{Hg}$.

\section{RESULTADOS Y DISCUSIÓN}

\section{1.- Descripción macroscópica de tapiales y adobe}

Las muestras de tapiales que han sido estudiadas presentan características similares en las iglesias de Cisneros y Villada, estando constituidos por una masa compacta y heterogénea de cantos redondeados de cuarzo, arena de granulometría muy variada y arcilla. Además se han podido observar otros componentes adicionales, algunos de los cuales son de gran tamaño (aproximadamente $3 \mathrm{~cm}$ ). Estos aditivos consisten en fragmentos de ladrillos, tejas, huesos, escorias y fragmentos de materia vegetal (palos, paja, etc.). También radiation and a graphite monochromator. Working conditions were as follows: intensity $30 \mathrm{~mA}$; potential $40 \mathrm{Kv}$, scan rate, $1^{\circ}$ of $2 \theta / \mathrm{min}$ and the zone explored 3$65^{\circ}$ of $2 \theta$.

To determine the mineral composition of the $<2 \mu \mathrm{m}$ fraction, separated by decantation, XRD analyses were conducted on oriented aggregates, solvating the samples with ethylene-glycol and subjecting the them to heat treatment (calcination at $550{ }^{\circ} \mathrm{C}$ ) for $2 \mathrm{~h}$.

To obtain thin sections, samples were embedded in polymetacrylate resin in vacuo to maintain the texture of the materials and to avoid, as far as possible, the loss of clay material in the process of slide polishing The slides were examined under a polarized light microscope and afforded data about the composition of the skeleton and of the matrix, acting as the dry part and binder of the mud, respectively, together with data on porosity.

A granulometric study was performed by sieving between 350 and $400 \mathrm{~g}$ of sample previously disintegrated with a dispersant to separate the different granulometric fractions. The dispersant employed was sodium hexametaphosphate at $7 \%$. After the sieving, each of the fractions retained in the different sieves was weighed. The sieves were chosen on the basis of the simplified analysis of Diaz et al. (9) -2, 0.4 and $0.08 \mathrm{~mm}$-interspersing sieves of 4, 1 and $0.177 \mathrm{~mm}$ between them. The succession was therefore 4, 2, 1, 0.4, 0.177 and $0.08 \mathrm{~mm}$.

Finally, study of the porous system of the mud walls was completed with the $\mathrm{Hg}$ Injection Porosimetry technique, using a Micromeretics model 9320 apparatus at a pressure ranging from 1 to 30.000 p.s.i. after previously degassing the samples up to a residual pressure of $50 \mathrm{~mm} \mathrm{Hg}$.

\section{RESULTS AND DISCUSSION}

\section{Macroscopic description of mud walls and adobe}

The mud-wall samples studied have the same characteristics at the churches of Cisneros and Villada and comprise a compact and heterogeneous mass of round clasts of quartz, sand of very different grain sizes, and clay. Other components were also observed, some of which were quite large (approximately $3 \mathrm{~cm}$ ). These included fragments of brick, roofing tiles, bones, hearth slag, and plant materials (twigs, straw etc). 
se han encontrado restos de cal, adición cuyo fin es dar estabilidad al tapial (7).

En observación con lupa binocular se puede apreciar una porosidad intergranular y porosidad de fisuras de pequeño tamaño que, en ocasiones, presentan formas poligonales. Dichas fisuras serían debidas a la retracción del tapial.

De todas estas observaciones puede concluirse que los tapiales son, a pequeña escala, muy heterogéneos, debido a una gran variedad composicional. Sin embargo, si se comparan las distintas muestras de la torre de Cisneros entre sí y la muestra de Villada se deduce que los tapiales presentan, a gran escala, una notable homogeneidad.

En la observación de la muestra de mano y con lupa binocular de la muestra BO1 se aprecia que las características del adobe son muy diferentes a las de los tapiales de las iglesias de Cisneros y Villada. En este caso el material de construcción es menos compacto y está constituido por arena, más fina que en los tapiales, arcilla y gran cantidad de paja, aditivo cuya misión era aportar cohesión interna y evitar la retracción del secado de los adobes. En esta muestra se aprecian restos de la lechada de restauración que ha colmatado el sistema poroso interior de los adobes. Se ha podido observar que, a simple vista, existe un mayor volumen de poros respecto a los tapiales de Cisneros y Villada.

\section{2.- Estudio petrográfico}

Se han obtenido datos referentes a la composición del esqueleto y de la matriz (que actuarían como el árido y el ligante del tapial) y características de la porosidad mediante el estudio de láminas delgadas al microscopio óptico de polarización.

Las características microscópicas de los tapiales de Cisneros y Villada son muy semejantes, presentando ligeras diferencias en cuanto a las proporciones de sus componentes (Figuras 4 y 5). Se trata de un material arenoso, matrizsoportado y cuyo esqueleto está constituido, fundamentalmente, por granos de cuarzo, calcita y fragmentos de roca arcillosos, cuarcíticos, carbonatados y arenosos. Asimismo, se han apreciado algunos restos de cal y fragmentos de origen orgánico. Se han observado granos de cuarzo monocristalino y policristalino. Son cristales angulosos y de un tamaño muy heterométrico, predominando los tamaños arena fina y limo. Los fragmentos de roca arcillosos y carbonatados presentan bordes muy redondeados. La matriz es fundamentalmente sericítica y arcillosa aunque localmente se aprecia la existencia de calcita micrítica.
Remains of lime-used to stabilize the walls-were also found (7).

Under the binocular light microscope, the material was seen to display an intergrain porosity and a slight fissure porosity, occasionally forming polygons. These fissures would be due to retraction of the wall.

From all the observations made it may be concluded that, at small scale, the mud walls are very heterogeneous owing to the strong variations in their composition. Despite this, on comparing the different samples taken from the tower of the church in Cisneros with each other and with the sample taken at Villada at large scale the mud walls appear to be fairly homogeneous.

From naked-eye and light microscopic observations of the BOI sainple, the characteristics of the adobe were seen to differ considerably from those of the mud walls of the churches in Cisneros and Villada. In this case, the construction material was less compact and comprised sand-finer than in the mud walls-, clay and a large amount of straw, used to provide internal cohesion and to avoid retraction when the adobe dries. This latter sample also had remains of the restoration slurry used to fill the inner pore system of the adobe. Even with no magnification it was possible to see that pore volume was greater than those found in the mud walls of the churches in Cisneros and Villada.

\section{Petrographic study}

Data on the composition of the skeleton and of the matrix (which would act as the hard grains and "cement" of the mud) and porosity characteristics were obtained by study under a polarized light microscope.

The microscopic characteristics of the mud walls at Cisneros and Villada are very similar, only small differences in the proportions of their components (Figures 4 and 5) being observed. The material is sandy, matrix-supported, and its skeleton is mainly composed of grains of quartz, calcite and fragments of clayey, carbonate and sandy rock. Some remains of lime and organic fragments were also observed. Both monocrystalline and polycrystalline quartz grains were seen. These were angular and were very heterogeneous in size, with a predominance of fine sand and silt. The matrix was essentially composed of sericite and clay, although local accumulations of micritic calcite were also seen. 


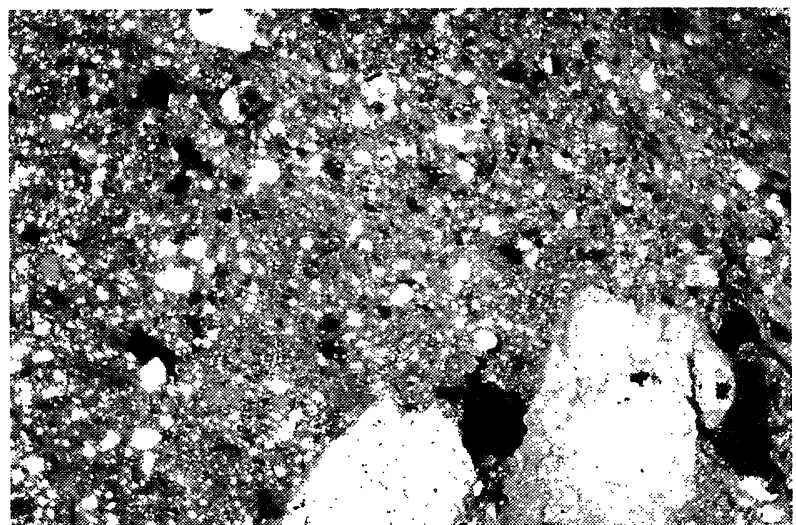

Figura 4.- Aspecto de la muestra CIS3 al microscopio óptico (NX, 12,5 aumentos).

Figure 4.- General view of the sample CIS3 by optical microscopy (x 12,5).

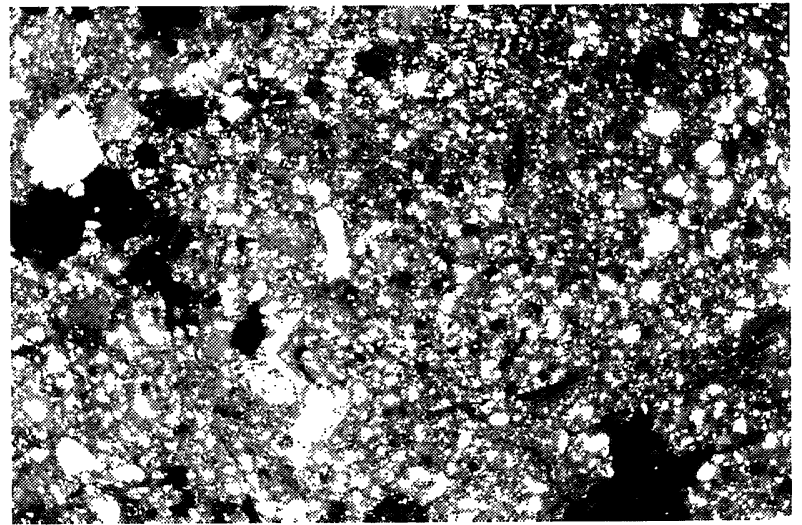

Figura 5.- Aspecto de la muestra V12 al microscopio óptico (NX, 12,5 aumentos).

Figure 5.-General view of the sample VI2 by optical microscopy $(x 12,5)$.

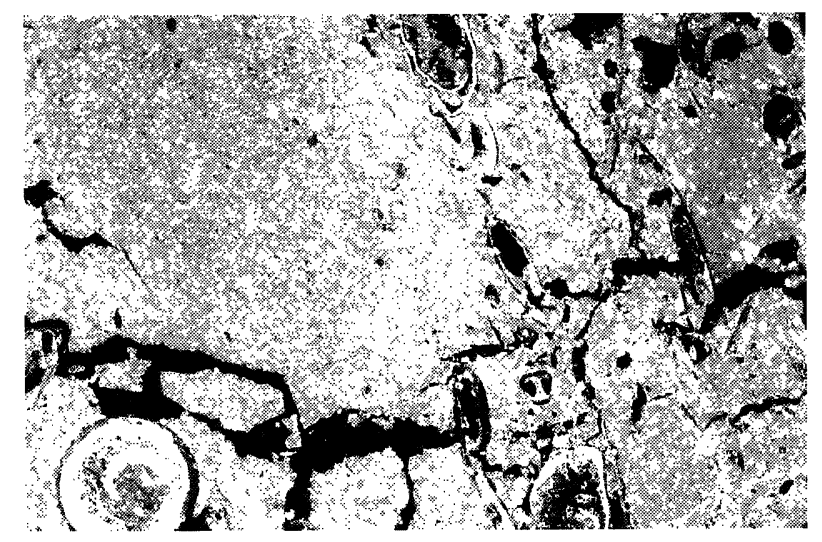

Figura 6.- Aspecto de la muestra BO1 al microscopio óptico (NX, 12,5 aumentos).

Figure 6.-General view of the sample BOI by optical microscopy (x 12,5).

Se observa porosidad de tres tipos, siendo la de mayor tamaño de tipo venoso $(100-300 \mu \mathrm{m})$. Existe también una porosidad de tipo caverna de tamaño muy variado y porosidad interpartícula de tamaño muy pequeño. Debido al pequeño tamaño del poro interpartícula, no se ha podido calcular el porcentaje de la porosidad empleando esta técnica.

Las características texturales del adobe son, cualitativa y cuantitativamente, diferentes de las del tapial (Figura 6). Es un material arenoso matrizsoportado cuyo esqueleto está constituido por granos de cuarzo, restos vegetales de paja, fragmentos de roca arcillosos, carbonatados y arenosos. Los componentes esqueléticos más grandes están constituidos por los restos vegetales de paja. Los granos de cuarzo son angulosos, de un tamaño menor
Three types of porosity were detected, the largest being of the venous type $(100-300 \mu \mathrm{m})$. A highly variable vug porosity was also seen, together with a very small interparticle porosity. Owing to the very small size of the interparticle pores, using this technique it was not possible to calculate the percentage of porosity.

The textural characteristics of the adobe were both qualitatively and quantitatively different from those of the mud walls (Figure 6). Adobe is a sandy matrixsupported material whose skeleton is formed by grains of quartz, the remains of straw, and fragments of clayey, carbonate and sandy rocks. The quartz grains are angular, smaller than those found in the mud walls, and have a large size range. The fragments of clayey and carbonate rocks are very 
que en el caso de los tapiales y muy heterométrico. Los fragmentos de roca arcillosos y carbonatados son muy redondeados. La matriz aparece en mayor proporción respecto a los tapiales y está constituida por minerales micáceos y arcillosos.

La porosidad es mayor y diferente que la de los tapiales, observándose porosidad de tipo venoso de mayor tamaño que en aquellos y porosidad de caverna e intragranular de unas dimensiones muy variables (entre $1 \mathrm{~mm}$ y $1 \mu \mathrm{m}$ ). Existe una importante porosidad intrapartícula que oscila entre $1 \mathrm{~mm}$ y $350 \mu \mathrm{m}$.

\section{3.- Análisis mineralógico por Difracción de Rayos-X}

Se ha realizado el estudio por Difracción de Rayos-X para muestras de roca total con el fin de conocer la composición global de los tapiales y del adobe de los edificios objeto de estudio.

El conocimiento de la composición mineralógica de los materiales es imprescindible para prever el comportamiento de los mismos ya que la presencia de arcillas expandibles podría ser causa de deterioro si existiesen cambios de humedad en el tapial, originados, bien por causas naturales, por el mal funcionamiento de los sistemas de evacuación de agua o, como es nuestro caso, por la inyección de lechada fluida en el proceso de restauración.

En las Figuras 7, 8 y 9 se muestran los difractogramas correspondientes a los análisis de roca total, agregado orientado, muestras solvatadas con etilén-glicol y muestras sometidas a tratamiento térmico para los tapiales CIS3 y VI2 y para el adobe BO1 respectivamente.

Del análisis de los datos de estos difractogramas se deduce que la composición semicuantitativa de las diferentes muestras, expresada en \%, es la que se expone en la Tabla I. Todas las muestras de tapiales y adobe analizadas son, desde un punto de vista mineralógico cualitativo, bastante similares y están compuestas fundamentalmente por cuarzo, illita y calcita. Se aprecian pequeñas cantidades de caolinita y, como minerales minoritarios, se han podido detectar feldespatos y dolomita. Estos componentes son característicos de los materiales sedimentarios existentes en la zona donde se ubican los tres edificios, materiales pertenecientes a la denominada Facies Tierra de Campos que es una unidad siliciclástica que incluye los depósitos lutítico-arenosos tradicionalmente denominados de Tierra de Campos y sus equivalentes (10). rounded. The matrix is present at greater proportions than in the mud walls and is formed of micaceous and clay minerals.

Porosity is greater and differs from that seen in the mud walls, with the observation of a more prominent venous porosity than in the case of the mud walls and $a$ vug and intragranular porosity whose dimensions vary considerably (between $1 \mathrm{~mm}$ and 1 $\mu \mathrm{m})$. An important degree of intraparticle porosity was seen, ranging between $1 \mathrm{~mm}$ and $350 \mu \mathrm{m}$.

\section{Mineralogical analysis by $X-R a y$ Diffraction}

Studies by X-Ray Diffraction were performed on whole rock samples with a view to determining the overall composition of the mud walls and of the adobe used in the construction of the buildings studied.

Knowledge of the mineralogical composition of materials is essential for the prediction of the future behaviour of the materials since the presence of swelling clays could lead to deterioration should changes occur in the original humidity of the mud walls; such changes would be due to natural causes poor functioning of the systems responsible for removing the water-or, as in our case, to the injection of a very fluid additive during the restoration process.

Figures 7, 8 and 9 show the diffractograms corresponding to the analyses of whole rock, oriented aggregates, samples solvated with ethylene-glycol and samples subjected to heat treatment for mud wall samples CIS3 and CI2 and for the adobe sample BOI, respectively.

From the analysis of the data provided by these diffractograms, it may be deduced that the semiquantitative composition of the different samples - expressed as percentages- is as seen in Table 1. From the qualitative mineralogical point of view, all the samples of mud wall and adobe analyzed are quite similar and are mainly composed of quartz, illite and calcite. Small amounts of kaolinite, and as minor accessories feldspars and dolomites, are also present. These components are characteristic of the sedimentary rocks found in the area harbouring the three buildings. These rocks belong to the so-called Tierra de Campos Facies, which is a siliciclastic unit that includes deposits of lutite-sandy materials traditionally known as Tierra de Campos and its equivalents (10). 


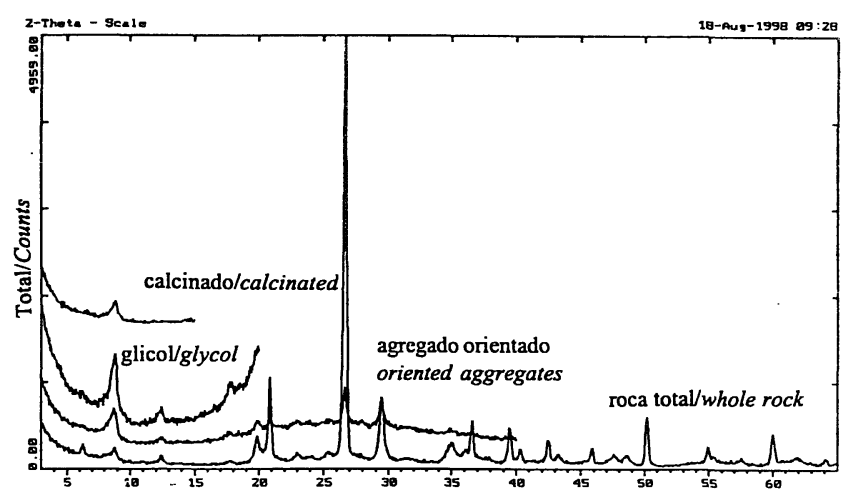

Figura 7.- Análisis DRX de roca total, agregado orientado, muestras solvatadas con etilén-glicol y muestras sometidas a tratamiento térmiદo del tapial de Cisneros (muestra CIS3).

Figure 7.- Sample CIS3. Diffractograms of unoriented powder and orientedaggregates under room conditions, solvated whith ethyleneglycol and calcined at $500{ }^{\circ} \mathrm{C}$.

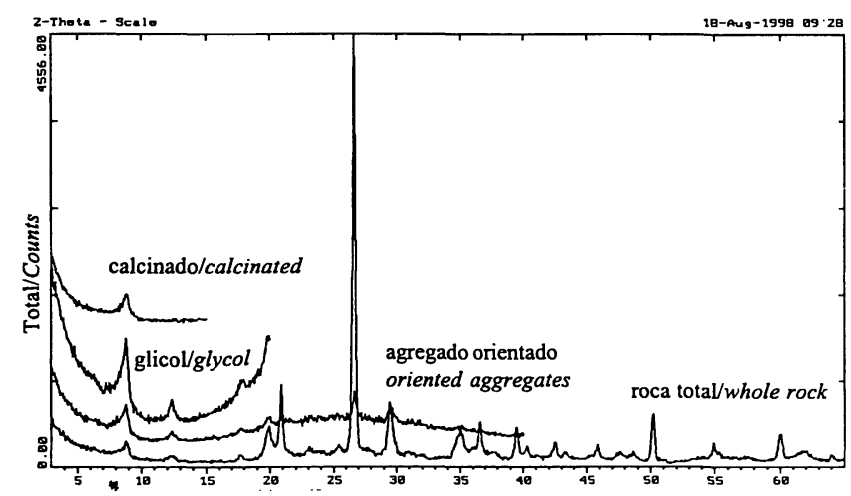

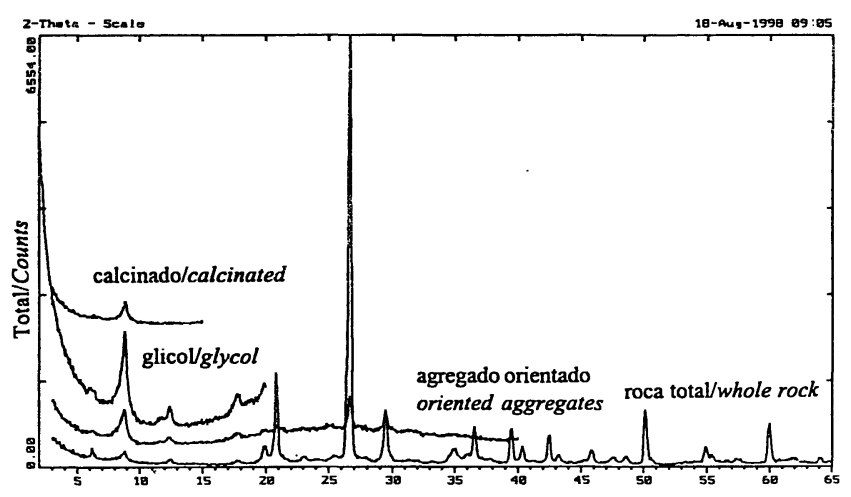

Figura 8.- Análisis DRX de roca total, agregado orientado, muestras solvatadas con etilén-glicol y muestras sometidas a tratamiento térmico del tapial de Villada (muestra V12).

Figure 8.- Sample VI2. Diffractograms of unoriented powder and orientedaggregates under room conditions, solvated whith ethyleneglycol and calcined at $500{ }^{\circ} \mathrm{C}$
Figura 9.- Análisis DRX de roca total, agregado orientado, muestras solvatadas con etilén-glicol y muestras sometidas a tratamiento térmico del adobe de Boada (muestra BO1)

Figure 9.- Sample BOI. Diffractograms of unoriented powder and orientedaggregates under room conditions, solvated whith ethylene-glycol and calcined at $500{ }^{\circ} \mathrm{C}$.

TABLA I (TABLE I)

Composición mineralógica semicuantitativa de tapiales y adobe

(Mineralogical composition of mud walls and adobe materials)

\begin{tabular}{|c|c|c|c|c|c|c|}
\hline \multirow{2}{*}{$\begin{array}{l}\text { Muestra } \\
\text { (Sample) }\end{array}$} & \multirow{2}{*}{$\begin{array}{c}\text { Cuarzo } \\
\text { (Quartz) } \\
(\%)\end{array}$} & \multirow{2}{*}{$\begin{array}{c}\text { Calcita } \\
\text { (Calcite) } \\
(\%)\end{array}$} & \multirow{2}{*}{$\begin{array}{c}\text { Feldespato } \\
\text { (Feldspar) } \\
(\%)\end{array}$} & \multirow{2}{*}{$\begin{array}{c}\text { Dolomita } \\
\text { ( (Dolomite) } \\
(\%)\end{array}$} & \multicolumn{2}{|c|}{$\begin{array}{c}\text { Filosilicatos } \\
\text { (Filosilicates) }\end{array}$} \\
\hline & & & & & $\begin{array}{c}\text { Illita } \\
\text { (Illite) }\end{array}$ & $\begin{array}{c}\text { Caolinita } \\
\text { (Caolinite) }\end{array}$ \\
\hline CIS1 & 44 & 15 & $\begin{array}{l}\text { Trazas } \\
\text { (Traces) }\end{array}$ & --- & 38 & 3 \\
\hline CIS2 & 44 & 18 & -- & --- & 35 & 3 \\
\hline CIS3 & 42 & 15 & -- & -- & 40 & 3 \\
\hline V12 & 57 & 12 & $\begin{array}{c}\text { Trazas } \\
\text { (Traces) }\end{array}$ & --- & 29 & 2 \\
\hline BO1 & 38 & 11 & --- & $\begin{array}{c}\text { Trazas } \\
\text { (Traces) }\end{array}$ & 47 & 4 \\
\hline
\end{tabular}


Desde un punto de vista mineralógico, los tapiales de Cisneros son muy homogéneos a gran escala. El tapial de Villada, respecto a los anteriores, posee contenidos en cuarzo ligeramente mayores y menor cantidad de filosilicatos, debido a la utilización en origen de una materia prima más arenosa que en Cisneros. La relación esqueleto/matriz arcillosa es de $3 / 2$ en los tapiales de Cisneros y de 7/3 en los tapiales de Villada. Los adobes de Boada se diferencian de los citados tapiales por estar formados con un alto contenido en minerales micáceos y arcillosos así como menores contenidos en cuarzo. Este hecho se explica por la utilización de un barro más arcilloso para la elaboración del adobe. La relación entre los componentes esqueléticos (exceptuando la paja) y matriz arcillosa es de $1 / 1$.

En todas las muestras destaca la ausencia de arcillas hinchables (esmectitas) capaces de retener importantes cantidades de agua.

No se han encontrado sales que derivarian de procesos de deterioro (11).

\section{4.- Granulometría}

Además de la composición mineralógica de tapiales y adobe, la granulometría (tamaño de grano) es una característica esencial a la hora de caracterizar un tapial ya que nos da idea del tipo de materia prima empleada en la elaboración de dichos tapiales y adobes. Los resultados de la granulometría se expresan en las curvas granulométricas de la Figura 10.
From a mineralogical point of view, at large scale the mud walls of the church in Cisneros are very homogeneous. In comparison with these, the mud walls of the church in Villada have slightly higher contents in quartz and slightly lower amounts of filosilicates; this is due to the original use of a more sandy raw material than in Cisneros. The skeleton/ clayey matrix ratio is $3 / 2$ in the mud walls of Cisneros and 7/3 in those of Villada. The Boada de Campos adobe differs from these mud walls in that it is formed of material with a high content in micaceous and clayey components and lower amounts of quartz. This is because a mud with a higher clay content was used to make the adobe. The ratio between skeletal components (with the exception of the straw) and the clay matrix is $1 / 1$.

In all samples studied, a striking finding was the absence of swelling clays (smectites) able to retain important amounts of water.

No salts deriving from processes of deterioration (11) were observed.

\section{Granulometry}

Apart from the mineralogical composition of the mud walls and adobe, granulometry (grain size) is an essential aspect to be taken into account when characterizing mud walls since this provides insight into the type of raw material originally used to make the mud walls and adobes. The results of the granulometric study are shown in the curve in Figure 10.

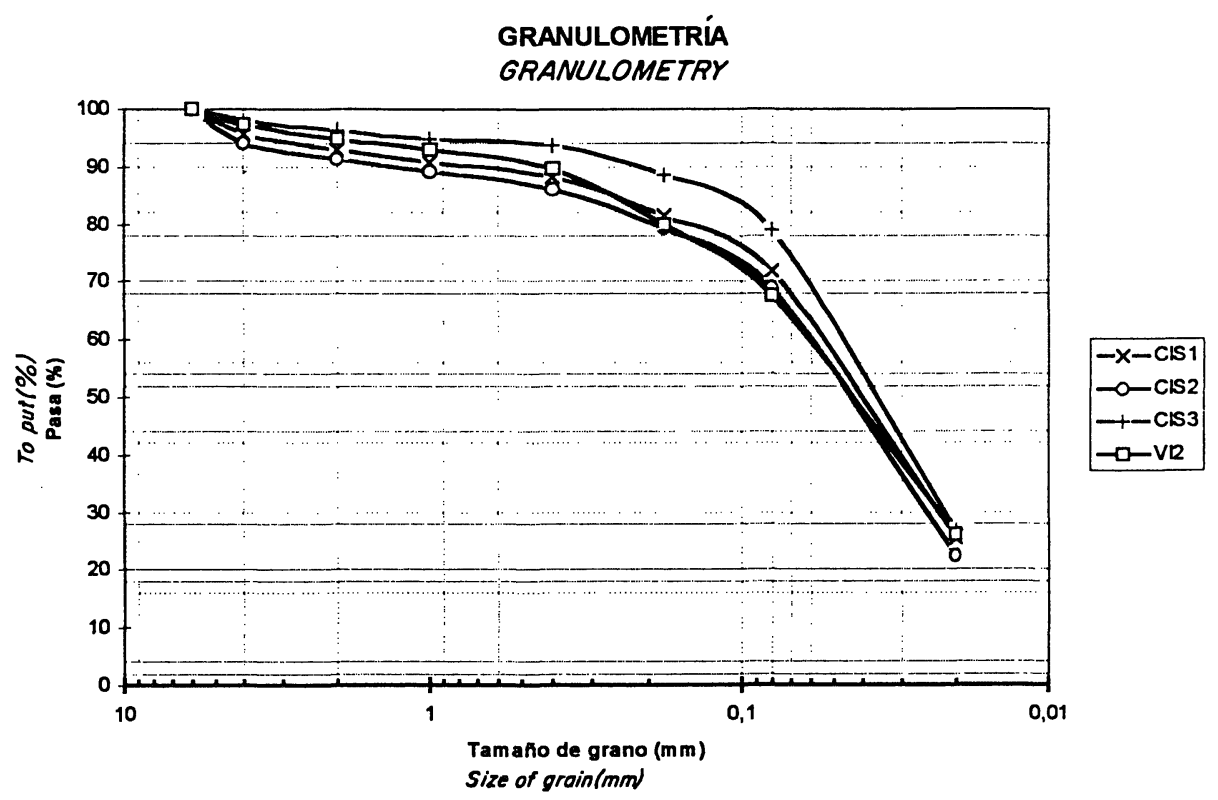

Figura 10.- Curvas granulométricas de las muestras CIS1, CIS2, CIS3 y V12.

Figure 10.- Granulometric curves of CISI, CIS2, CIS3 and VI2. 
La curva granulométrica de la muestra $\mathrm{BO} 1$ no ha sido determinada ya que el elevado porcentaje de material vegetal (paja) existente y la presencia de lechada de restauración rellenando los poros mayores del adobe, falsearian los datos de la granulometría. En Villada sí ha sido factible la realización de la granulometría ya que los fragmentos de tapial que fueron empleados, se encontraban libres de lechada de mortero.

Las curvas granulométricas de estos tapiales corroboran las observaciones al microscopio e indican una granulometría muy heterométrica, predominando los tamaños muy finos y arcillosos. En los tapiales analizados, entre el 67 y el $80 \%$ de los granos de la muestra pasan por el tamiz de $0,08 \mathrm{~mm}$, porcentajes similares a los de las tierras empleadas en otras construcciones como, por ejemplo, las de la localidad de Navapalos (9). Por ello, los materiales con los que fueron construidos los tapiales proceden de terrenos que pueden clasificarse como finos según la clasificación H.R.B. (tomado de 9) ya que en todas las muestras estudiadas el porcentaje de material que pasa por el tamiz de $80 \mathrm{~mm}$ es mayor del $35 \%$.

\section{6.- Estudio de la porosidad. Porosimetría de Inyección de $\mathbf{H g}$}

Esta técnica permite conocer la porosidad total de la muestra y el volumen de poros correspondientes a cada tamaño. El conocimiento del tamaño de poros es importante ya que éste regula la dinámica de los fluidos dentro del tapial e incide directamente en los procesos de alteración. El estudio de la porosidad se ha realizado, únicamente, sobre las tres muestras de tapial de la iglesia de Cisneros.

El dato de la porosidad abierta y densidades real y aparente, obtenidas mediante la técnica de Porosimetría de Inyección de $\mathrm{Hg}$, son las que se muestran en la Tabla II.
The granulometric curve of sample BOI was not determined because the high content in plant matter (straw) and the presence of the cement injected in the restoration -which filled the larger pores of the adobe-would have biased the data. At Villada, however, it was possible to conduct a granulometric study since the fragments from the mud wall used were not contaminated by the introduction of the restoration mortar.

The granulometric curves of these mud walls corroborate the microscopic observations and point to a highly heterometric granulometry, with a predominance of very fine and clayey components. In the mud wall samples analyzed, between $67 \%$ and $80 \%$ of the grains of the sample passed through a $0.08 \mathrm{~mm}$ sieve. These percentages are very similar to those of the mud used at other sites, such as at Navapalos (9). Accordingly, the materials with which the mud walls were constructed must have come from terrain that can be classified as fine according to the H.R. B. classification (taken from ref. 9) since in all the materials studied the percentage of material able to pass through an $80 \mathrm{~mm}$ sieve was more than $35 \%$.

\section{Study of porosity. $\mathrm{Hg}$ Injection Porosimetry}

This technique affords information about the total porosity of the sample and of the pore volume of each sample. Knowledge of pore size is important since this is responsible for the fluid dynamics occurring in the mud walls and directly affects weathering processes. Study of porosity was only carried out on three samples from the mud walls of the church in Cisneros.

The data on open pores and real and apparent densities, obtained by $\mathrm{Hg}$ Injection Porosimetry, are shown in Table II

TABLA II (TABLE II)

Resultados de la Porosimetría de Inyección de mercurio sobre las muestras de tapial de Cisneros (Numerical results from Porosimetry of $\mathrm{Hg}$ )

\begin{tabular}{|c|c|c|c|}
\hline \hline $\begin{array}{c}\text { Muestra } \\
\text { (Sample) }\end{array}$ & $\begin{array}{c}\text { Densidad Real } \\
\text { (Real density) } \\
(\mathrm{g} / \mathrm{ml})\end{array}$ & $\begin{array}{c}\text { Densidad aparente } \\
\text { (Apparent density) } \\
(\mathrm{g} / \mathrm{ml})\end{array}$ & $\begin{array}{c}\text { Porosidad } \\
\text { (Porosity) } \\
(\%)\end{array}$ \\
\hline CIS1 & 2,6872 & 1,8198 & 32 \\
\hline CIS2 & 2,6272 & 1,7652 & 33 \\
\hline CIS3 & 2,6041 & 1,6525 & 36 \\
\hline
\end{tabular}


Además, esta técnica permite conocer la distribución porométrica del material. Las curvas porosimétricas que se muestran en la Figura 11 dan idea de la distribución cuantitativa de los distintos diámetros de los poros accesibles al mercurio.

Observando las curvas porosimétricas para las tres muestras de Cisneros, en las que se representa el logaritmo diferencial de intrusión frente al diámetro de poros, se aprecia que las muestras CIS1, CIS2 y CIS3 presentan una distribución porosimétrica análoga, por lo que su comportamiento frente a variaciones de humedad será similar.

El mayor volumen de poros se distribuye en el rango de la microporosidad alrededor de $0,2-0,3 \mu \mathrm{m}$. Existe también un volumen de porosidad importante en $200 \mu \mathrm{m}$, dentro del rango de la macroporosidad.
This technique also provides information about the porometric distribution of the material. The porosimetric curves are shown in Figure 11 and give an idea of the quantitative distribution of the different pore diameters accessible to the mercury.

Scrutiny of the porosimetric curves of the three samples from Cisneros, representing the differential logarithm of intrusion versus pore diameter, reveals that samples CIS1, CIS2 and CIS3 have a similar pore distribution, such that their behaviour when challenged by different variations in humidity would be similar.

The highest pore volume lies within a microporosity range of 0.2-0.3 $\mu \mathrm{m}$. There is also an important pore volume at $200 \mu \mathrm{m}$, within the macropore range.

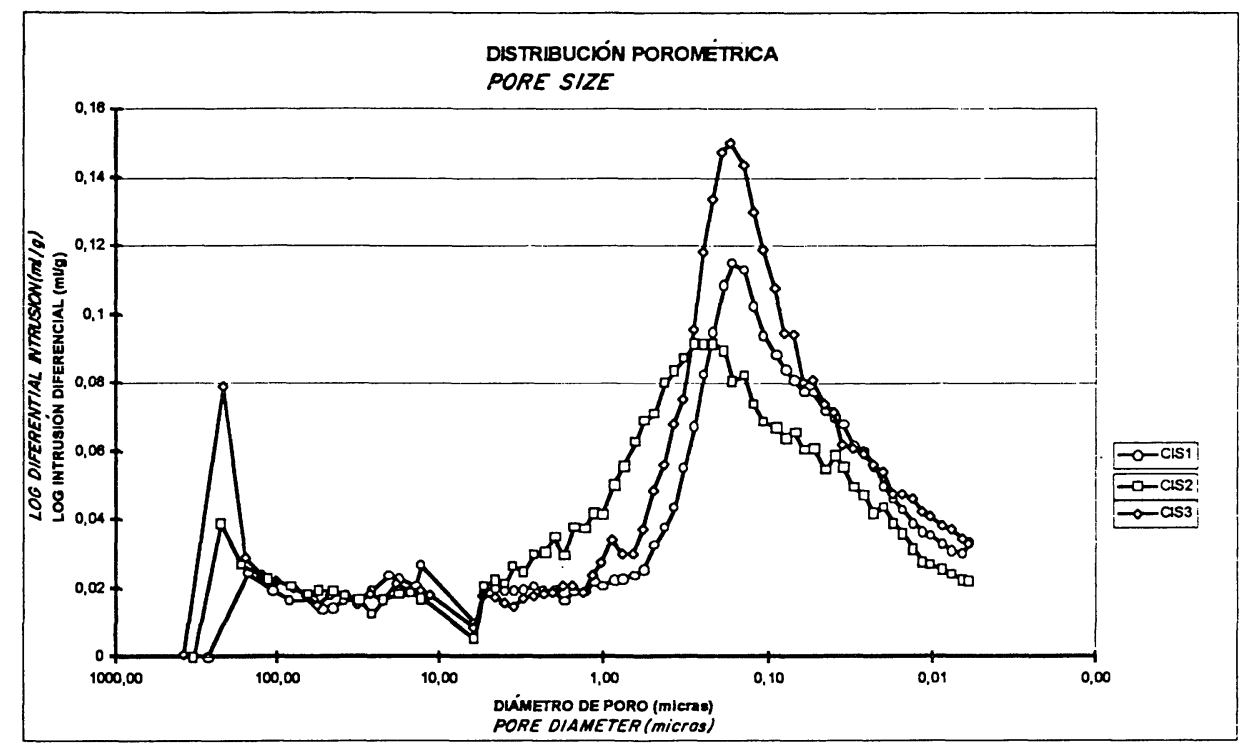

Figura 11.- Porosimetría de Inyección de Hg. Curvas de distribución porométrica para los tapiales de Cisneros.

Figure 11.- Curves of pore size from Porosimetry of $\mathrm{Hg}$.

\section{CONCLUSIONES}

Las observaciones realizadas indican que las muestras de tapial de Cisneros (CIS1, CIS2 y CIS3) son, composicional y texturalmente, muy similares entre sí lo que indica que, a pesar de ser una torre de grandes dimensiones, se cuidó la homogeneidad en la composición de los materiales y su construcción. Estas muestras de tapial guardan una notable similitud con la muestra estudiada de la iglesia de localidad de Villada.

\section{CONCLUSIONS}

The results of the present study indicate that the mud-wall materials of Cisneros (CIS1, CIS2 and CIS3) are texturally and compositionally similar, showing that despite its large size great care was taken to ensure that the materials used to construct the tower would be homogeneous. These mud-wall samples are very similar to the sample taken from the church in Villada. 
Los tapiales de las torres están construidos con una materia prima original a base de barro con algunos aditivos (escombro, cenizas, huesos, etc.) y algunos restos de cal empleada como estabilizante. El tapial tiene una proporción de arcilla muy elevada respecto a los materiales arenosos (relación esqueleto/arcillas de $3 / 2$ en Cisneros y $7 / 3$ en Villada). Sin embargo, no se han detectado arcillas hinchables por lo que, se deduce que una vez construido el tapial no se habrían producido importantes cambios de volumen por variaciones de humedad de las fábricas aunque sí se han observado pequeñas fisuras debidas a retracción. La porosidad en los tapiales es elevada, oscilando entre el 32 y el $36 \%$ siendo fundamentalmente de tipo intrapartícula y venoso. La granulometría indica materias primas con granulometría uniforme, pero con mala gradación.

Las características del adobe de la torre de Boada son, lógicamente, diferentes de las de los tapiales anteriormente citados, estando constituido por un barro menos arenoso, más arcilloso, con una elevada proporción de paja (ausente los tapiales) y, a diferencia de éstos, no contiene adiciones de ladrillos, huesos, etc. El tamaño de grano de los componentes esqueléticos, exceptuando la paja, es sensiblemente menor que en los tapiales. La relación esqueleto/ arcillas es de 1/1. La porosidad en el adobe es más abundante y de mayor tamaño.

\section{AGRADECIMLENTOS}

A Juan Manuel Cabero(CABEROEDIFICACIONES, S.A.) por las facilidades prestadas para la realización de este trabajo y por el interés mostrado en los resultados del mismo.
The walls of the towers are made of an original raw material based on mud and some additives (rubble, ash, bones, etc) and small amounts of lime used as a stabilizer. The composition of the mud walls has a high proportion of clay with respect to sandy materials (skeleton/matrix ratio $2 / 3$ at Cisneros and $7 / 3$ at Villada). Nonetheless, no swelling clays were observed, such that it would appear that after the mud walls had been built no changes in volume due to variations in the humidity of the fabric would have occurred, although small fissures due to retraction are visible. The porosity in the mud walls is high, ranging from 32 to $36 \%$ and essentially being of the intraparticle and venous type. The results of the granulometric studies point to raw materials with a uniform granulometry but with a poor gradation.

The characteristics of the adobe of the church tower in Boada de Campos are logically different from the above materials and feature a less sandy mud, with a higher clay content, a high proportion of straw (which is not present in the mud walls) and, unlike the mud walls, no additions of brick, bones, etc. The large grain size of the skeletal components, with the exception of straw, is appreciably greater than that seen in the mud walls. The skeleton/matrix ratio is $1 /$ 1. The porosity in the adobe is more abundant and larger.

\section{ACKNOWLEDGEMENTS}

The authors wish to thank Mr. Juan Manuel Cabero (CABERO EDIFICACIONES) for his assistence.

\section{BIBLIOGRAFÍA}

(1) Guinea, M.J.: “Consolidación, mejora y nuevas técnicas de construcción con tierra." Jornadas sobre conservación y restauración de monumentos. Madrid, 24 y 25 de abril de 1989. Ministerio de Cultura. Dirección General de Bellas artes y Archivos(1991), pp 135-142.

(2) Algorri, E.: "Tres soluciones en la restauración del Palacio de Toral de los Guzmanes. León-España". Informes de la Construcción, Vol. 46. $n^{\circ} 434$ (1994), pp 27-38.

(3) Gárate, I.: "La construcción en tierra, objeto de restauración". Monografias IETCC CSIC n 385-386 (1987), pp. 45-48.

(4) González, I.: "Muralla de Niebla, Huelva". Jornadas sobre conservación y restauración de monumentos. Madrid, 24 y 25 de abril de 1989. Ministerio de Cultura. Dirección General de Bellas Artes y Archivos (1991), pp 143-148.

(5) Matas, M.: "Intervenciones en las murallas de Cáceres." En "La ciudad y sus murallas" Universidad de Granada (1996), pp. $261-280$.

(6) Gallego, F.J.: "La Torre de La Sultana, de Los Adarves o de arriate en la Alhambra de Granada". Monografias IETCC-CSICn ${ }^{\circ} 385$ 386 (1987), pp. 49-56.

(7) Algorri, E. Y Vázquez, M.: "Rehabilitación del Castillo de Toral de los Guzmanes." Jornadas sobre conservación y restauración de monumentos. Madrid, 24 y 25 de abril de 1989. Ministerio de Cultura. Dirección General de Bellas Artes y Archivos (1991), pp 149-164.

(8) Jurado, F.: "Rehabilitación de la Casa-Castillo de Bátera, Valencia" Monografias IETCC-CSIC n ${ }^{\circ} 385-386$ (1987), pp. 63-65.

(9) Diaz, J. Guinea, M.A., Rohmer, E. Y Salas, J.: "Primeros resultados del trabajo de investigación sobre la tierra como material de construcción" Informes de la Construcción. IETCC-CSIC n" 37-337 (1986), pp. 5-20.

(10) Siemcalsa: "Mapa Geológico y Minero de Castilla y León." Junta de Castilla y León (1997).

(11) Ontiveros. E, Valverde, I., Sebastián, E.: "Técnicas de análisis aplicadas al estudio de los tapiales de las murallas de Granada". III Congr. Int. Rehabilitación del Patrimonio Arquitectónico y Restauración (1996), pp 270-271. 